\title{
Pelatihan Membaca dan Menulis Puisi pada Peserta Didik TPA Al-Husna
}

\author{
Poetry Reading and Writing Training for TPA Al-Husna Students
}

\author{
Tutut Rahayu ${ }^{1}$, Prasetyo Yuli Kurniawan*2 \\ 1,2Program Studi Pendidikan Bahasa dan Sastra Indonesia, Fakultas Keguruan dan Ilmu Pendidikan, \\ Universitas Muhadi Setiabudi, Indonesia \\ e-mail :1 tututrahayu0400@gmail.com, ${ }^{* 2}$ prasetyoyulikurniawan@gmail.com
}

\begin{abstract}
Abstrak
TPA Al-Husna merupakan salah satu lemabaga pendidikan Al-Qur'an yang terletak di dusun Karang Tengah desa Rungkang. TPA Al-Husna juga merupakan salah satu pendidikan AlQur'an yang sudah lama berdiri yaitu tahun 2008 yang sampai sekarang sudah memiliki peserta didik yang lumayan banyak. Namun setelah dilakukannya observasi pada TPA AlHusna, pesrta didik belum memahami bagaimana membaca dan menulis puisi secara benar sesuai dengan kaidah puisi. Oleh karena itu, perlu pelatihan membaca dana menulis puisi yang menuntun untuk lebih bisa memilah-milah kosa kata yang nantinya akah disusun dalam sebuah puisi. Selain itu juga peserta didik di ajarkan supaya mampu membaca puisi secara benar dengan menggunakan ritma dan irama puisi, sehingga maksud dari puisi dapat tersampaikan kepada pendengar. Kegiatan ini bertujuan untuk melatih supaya peserta didik mampu menuangkan ide atau gagasan, pikiran serta perasaannya dalam kegiatan menulis puisi, karena dengan melatih peserta didik untuk menulis puisi diharapkan peserta didik dapat meningkatkan daya kreatifitas, daya imajinasi dan daya pikir, serta peserta didik mampu membaca puisi lewat susunan bait dan baris serta permainan bunyi. Metode yang digunakan dalam pelatihan ini yaitu metode ceramah, metode latihan, dan metode penugasan yang berlokasi di TPA Al-Husna. Secara keseluruhan hasil yang diperoleh dari kegiatan ini yaitu meningkatnya pemahaman peserta didik mengenai membaca dan menulis puisi dengan nilai persentase bahwa pemahaman peserta didik awal yaitu 30,4\%, kemudian pemahaman akhir peserta didik yaitu sejumlah 68\%, maka ada kenaikan 37,60\% dalam pemahaman membaca dan menulis puisi. Dalam hal ini berarti peserta didik setelah mendapatkan pelatihan ini mampu untuk membaca dan menulis puisi dengan baik dan benar.
\end{abstract}

Kata Kunci : Keterampilan Membaca, Keterampilan Menulis, Puisi, Menulis Puisi.

\begin{abstract}
TPA Al-Husna, is one of the Qur'anic educational institutions located in Karang Tengah hamlet, Rungkang village. TPA Al-Husna is also one of the Qur'anic education that has been established for a long time, namely in 2008 which until now has had quite a lot of students. However, after observing the Al-Husna TPA, the students did not understand how to read and write poetry correctly in accordance with the rules of poetry. Therefore, it is necessary to have training in reading and writing poetry that leads to better being able to sort out vocabulary which will later be compiled in a poem. In addition, students are taught to be able to read poetry correctly by using the rhythm and rhythm of the poem, so that the meaning of the poem can be conveyed to the listener. This activity aims to train students to be able to express ideas, thoughts and feelings in poetry writing activities, because by training students to write poetry, it is hoped that students can increase their creativity, imagination and thinking power, and students are able to read poetry. through the arrangement of stanzas and lines and sound play. The methods used in this training are the lecture method, exercise method, and assignment method located at TPA Al-Husna. Overall the results obtained from this activity are increasing students' understanding of reading and writing poetry with a percentage value that the initial understanding of students is $30.4 \%$, then the final understanding of students is $68 \%$, then there
\end{abstract}

Submitted: Agustus 2021, Accepted: Agustus 2021, Published: Agustus 2021

ISSN 2746-6345 (media online) 
is an increase of $37.60 \%$ in comprehension of reading and writing poetry. In this case, it means that after receiving this training, students are able to read and write poetry properly and correctly.

Keyword: Reading Skills, Writing Skills, Poetry, Poetry Writing.

\section{PENDAHULUAN}

Bahasa merupakan salah satu alat komunikasi dan interaksi yang digunakan manusia untuk berhubungan dengan manusia lainnya. Bahasa juga digunakan manusia sebagai alat yang paling penting bagi kelancaran komunikasi, karena bahasa dapat menyampaikan segala bentuk pemikiran manusia.

Keterampilan berbahasa terdiri dari beberapa aspek yaitu keterampilan meyimak, berbicara, menulis, dan membaca. Dalam hal ini keterampilan menulis dan keterampilan membaca sangat di perhatikan bagi peserta didik di berbagai jenjang pendidikan khususnya sekolah dasar. (Nurgiyantoro dalam Idawati dkk, 2021, p. 54) mengungkapkan bahwa menulis adalah aktivitas mengungkapkan gagasan melalui media bahasa. Sedangkan menurut (Tarigan, 2013, p. 3) menulis merupakan suatu keterampilan berbahasa yang dipergunakan untuk berkomunikasi secara tidak langsung, tidak secara tatap muka dengan orang lain. Menulis merupakan suatu kegiatan yang produktif dan ekspresif. Menulis dapat dikatakan suatu keterampilan berbahasa yang paling rumit di antara keterampilan berbahasa yang lainnya, ini karena menulis bukanlah sekedar menyalin kata-kata dan kalimat-kalimat melainkan juga mengembangkan dan menuangkan pikiran-pikiran dalam suatu struktur tulisan yang teratur (Nalenan, 2020, p. 93-94). Berdasarkan uraian beberapa ahli diatas dapat disimpulkan bahwa menulis adalah suatu keterampilan yang dimiliki seseorang untuk mengungkapkan gagasan tidak secara langsung melainkan secara tersurat. Pengajaran keterampilan menulis mempunyai tujuan yang artinya siswa dapat menerapkan materi dalam bentuk tulisan, bukan sekedar teori yang harus dipahami atau dihafalkan dan dengan mudah bisa dilupakan (Prayogi, 2017, p. 53).

Keterampilan berbahasa tidak hanya keterampilan menulis menlainkan keterampilan membaca. Menurut (Tarigan, 2015, p. 11) membaca adalah suatu keterampilan yang kompleks, yang rumit, yang mencakup atau melibatkan serangkaian keterampilan-keterampilan yang lebih kecil. Membaca adalah aktivitas reseptif seorang pembaca terhadap tulisan yang menjadi objek bacaanya. Dalam kegiatan membaca, pembaca berusaha memahami maksud dari seorang penulis, untuk mencari dan memahami informasi yang dituangkan oleh penulis. Bukan hanya maksud yang tersurat di dalam bacaan, tapi lebih dari itu, pembaca berusaha mencari makna tersirat dari suatu bacaan (Alfiansyah dan Yanti, 2020, p. 29). Berdasarkan uraian beberapa ahli diatas dapat disimpulkan bahwa keterampilan membaca adalah proses mengungkapkan suatu tulisan supaya pembaca untuk memperoleh pesan, yang hendak disampaikan oleh penulis melalui kata-kata secara tersurat.

Keterampilan menulis dapat terlihat pada penggunaan media gambar dalam menumbuhkan nilai-nilai karakter. Dengan adanya pelatihan tersebut dapat meningkatkan pemahaman peserta didik dalam memahami menulis deskripsi bagi peserta didik. Jadi, keterampilan menulis sesuai diterapkan dalam pembelajaran (Prasetyo Yuli Kurniawan, 2021).

Pembelajaran sastra di sekolah dasar sangat beragam. Selain pembelajaran sastra melalui prosa dan drama, terdapat pula pembelajaran sastra melalui puisi. Puisi memiliki berbagai manfaat jika diapresiasikan, seperti membaca puisi. membaca puisi berbeda dengan membaca biasa. Membaca puisi si pembaca dituntut untuk dapat memuaskan pendengar. Karena membaca puisi bagian dari seni (Yono, 2020, p. 104). Sedangkan menurut (Nurhadi dalam Utami dkk, 2018, p. 142) merupakan karya sastra yang berisi gagasan penyair dengan bahasa yang padat, singkat, dan menggunakan irama dengan bunyi yang padu dan pemilihan kata-kata kias (imajinatif).

Puisi juga mengelspresikan pemikiran yang membangkitkan perasaan, yang merangsang imajiniasi panca indera dalam susunan yang berirama. Semua itu, merupakan sesuatu yang penting, yang direkam dan diekspresikan, dinyatakan dengan menarik dan memberi kesan. Puisi itu merupakan rekaman interpretasi pengalaman manusia yang penting, digubah dalam wujud yang paling berkesan (Pradopo, 2012 p. 7). Jadi dapat disimpulkan bahwa puisi yaitu suatu 
karya sastra yang menggunakan bahasa yang telah dipadatkan, berisi imaji, dengan pemilihan diksi yang sesuai dengan gagasan yang akan disampaikan penulis kepada pembaca serta diberi iram dan ritma bunyi sehingga memperindah, mempertajam, dan memperjelas maksud dari sebuah puisi tersebut.

Puisi sangat penting dipelajari oleh peserta didik. Adapun beberapa manfaat mempelajari puisi yakni (1) puisi dapat memberikan wadah yang positif untuk siswa dalam berekspresi, menulis, dan berimajinasi dengan apa yang mereka rasakan, (2) pembelajaran menulis puisi sejatinya menumbuhkan minat siswa terhadap pembelajaran bahasa Indonesia khususnya pada bidang sastra, (3) siswa berkreasi dengan aturan-aturan penulisan puisi yang mereka sadari atau tidak melibatkan pola pikir mereka terhadap pembelajaran yang lebih bermakna, (4) puisi disamping sebagai wahana edukasi yang mendidik, puisi juga berkontribusi mengarahkan siswa mengenali potensi diri, mendorong siswa aktif belajar dan membiasakan berpikir serta memberikan kesempatan siswa menuangkan realitas hidupnya yang dikreasikan dengan daya imajinasinya sendiri (Kertayasa dkk, 2018, p. 249).

TPA Al-Husna merupakan salah satu lemabaga pendidikan Al-Qur'an yang terletak di dusun Karang Tengah desa Rungkang kecamatan Losari kabupaten Brebes. TPA Al-Husna dipimpin oleh ustaz Lukman, S.Pd.I. selaku ustaz dan imam di desa tersebut, TPA Al-Husna memiliki peserta didik lumayan banyak, mulai dari tingkat TK sampai Sekolah Menengah Pertama (SMP). TPA Al-Husna juga merupakan salah satu pendidikan Al-Qur'an yang sudah lama berdiri yaitu tahun 2008, yang bermula dari menginduk di TPA lain yaitu TPA Miftahul Huda sampai mempunyai TPA sendiri yang sekarang dikenal dengan TPA Al-Husna.

Setelah dilakukannya observasi dan pengamatan di TPA Al-Husna dusun Karang Tengah desa Rungkang, peserta didik belum mengerti cara membaca dan menulis puisi yang baik. Peserta didik hanya mengetahui puisi namum belum mengetahui mengenai cara menulis puisi dan membacanya sesuai dengan kaidah puisi. Dalam hal ini berarti peserta didik baik kelas tinggi maupun kelas rendah belum mengetahui bagaimana puisi yang baik itu, cara menulis maupun membacanya sehingga mereka membaca puisi seperti membaca buku, koran atau lainnya. Dengan fenomenal tersebut dapat disimpulkan bahwa peserta didik TPA Al-Husna belum mengetahui tata cara penulisan puisi yang baik dan bagaimana cara membaca puisi yang susai dengan ritma dan irama puisi. Dengan demikian masih rendahnya pengetahuan peserta didik mengenai puisi, sehingga perlunya pelatihan bagaimana menulis dan membaca puisi. Melalui pelatihan membaca dan menulis puisi ini diharapkan peserta didik mampu untuk merangkai kata-kata indah menjadi suatu puisi yang sesuai dengan kaidah puisi dan cara membaca puisi yang baik diiringi dengan ritma dan irama puisi itu sendiri sehingga pesan yang disampaikan oleh penulis sampai kepada pembaca.

Berdasarkan permasalahan yang ada di TPA Al-Husna dusun Karang Tengah desa Rungkang, maka perlu dilakukan kegiatan pengabdian yaitu tentang "Pelatihan Membaca dan Menulis Puisi pada Peserta Didik TPA Al-Husna”.

Tujuan dilakukan pengabdian masyarakat ini, antara lain; untuk memberikan pengertian dan pemahaman kepada peserta didik TPA Al-Husna dusun Karang Tengah desa Rungkang mengenai teori puisi, untuk memberikan keterampilan membaca dan menulis puisi kepada peserta didik TPA Al-Husna dusun Karang Tengah desa Rungkang.

Dalam rangka mengatasi permasalahan peserta didik di TPA Al-Husna dususn Karang Tengah desa Rungkang diberikan beberapa solusi yaitu memberikan materi terkait teori-teori membaca dan menulis puisi kepada peserta didik TPA Al-Husna dusun Karang Tengah desa Rungkang, memberikan pelatihan membaca dan menulis puisi kepada peserta didik TPA Al-Husna dusun Karang Tengah desa Rungkang dan menugaskan peserta didik TPA Al-Husna untuk membaca dan menulis puisi.

\section{METODE PELAKSANAAN}

Pada metode pelaksanaan kegiatan pengabdian pada masyarakat ini bertempat di TPA Al-Husna. Waktu pelaksanaan pengabdian pada hari Selasa, tanggal 7 September 2021. Alat yang digunakan selama kegiatan adalah papan tulis, alat tulis, dan kamera. Pelaksanaan 
pengabdian masyarakat ini terdapat beberapa pembahasan, yaitu; sasaran pengabdian masyarakat, tahapan pelaksanaan pengabdian masyarakat, dan proses pengabdian masyarakat. Hal ini dapat dijelaskan sebagai berikut.

\section{Sasaran Pengabdian Masyarakat}

Sasaran pengabdian ini yaitu peserta didik TPA Al-Husna dusun Karang Tengah desa Rungkang. Khalayak tersebut berdasarkan karakteristik peserta didik yang masih di jenjang Sekolah Dasar maupaun Sekolah Menengah Pertama (SMP/MTs). Hal tersebut disesuaikan dengan materi yang akan diberikan dalam pelatihan yaitu membaca dan menulis puisi.

Pelaksanaan pengabdian ini melibatkan banyak pihak. Pihak tersebut meliputi, Kepala TPA Al-Husna dusun Karang Tengah desa Rungkang, pendidik TPA Al-Husna, dan masyarakat sekitar yang membantu dalam terlaksananya kegiatan pengabdian berupa pelatihan membaca dan menulis puisi.

\section{Tahapan Pelaksanaan Pengabdian Masyarakat}

Permasalahan yang terjadi di TPA Al-Husna dusun Karang Tengah desa Rungkang yaitu masih kurang memahami teori membaca dan menulis puisi serta bagaimana cara untuk mempraktikkannya. Permasalahan tersebut dapat diselesaikan dengan beberapa tahap yaitu sebagai berikut.

a. Tahap Ceramah

b. Tahap Pelatihan Membaca dan Menulis

c. Tahap Penugasan

\section{Proses Pengabdian kepada Masyarakat dan Teknik Analisis}

Ada dua proses dalam pengabdian kepada masyarakat yang dapat diurutkan yaitu kegiatan awal, dan kegiatan inti. Hal tersebut dapat dijelaskan sebagai berikut.

a. Kegiatan Awal Pengabdian Masyarakat

Pada kegiatan awal pengabdian masyarakat ini, peserta didik TPA Al-Husna diberikan motivasi yang menjadikan peserta didik dapat mengikuti pelatihan dengan sangat baik. Hal tersebut dilakukan sebagai upaya kelancaran dan kesuksesan dalam melaksanakan pelatihan kepada peserta didik. Kemudian, peserta didik diberikan pemahaman awal tentang puisi yaitu bagiaman menulis dan membaca puisi yang baik dan benar sesuai dengan kaidah puisi. Pada kegiatan awal pengabdian ini juga bertujuan untuk melihat dan mengamati apakah peserta didik tertarik dengan puisi atau tidak, supaya ketika dalam pelaksanaan pengabdian dapat terlaksana dengan baik, dan peserta didik pun tidak merasa jenuh atau bosan dalam mengikuti pengabdian.

Teknik analisis yang digunakan pada kegiatan awal pengabdian ini yaitu teknik angket. Teknik angket ini digunakan untuk mengetahui bagaimana pemahaman awal peserta didik TPA Al-Husna dusun Karang Tengah desa Rungkang mengenai membaca dan menulis puisi. Dari hasil angket tersebut dapat diperoleh data awal pemahaman yang disajikan dalam bentuk tabel. Ada beberapa hal yang ditanyakan dalam angket, yaitu pengertian puisi, bagaimana cara membaca puisi, ciri-ciri menulis puisi, macam-macam puisi, dan langkah-langkah menulis puisi. Pada kegiatan awal dapat dilihat pada Gambar 1.

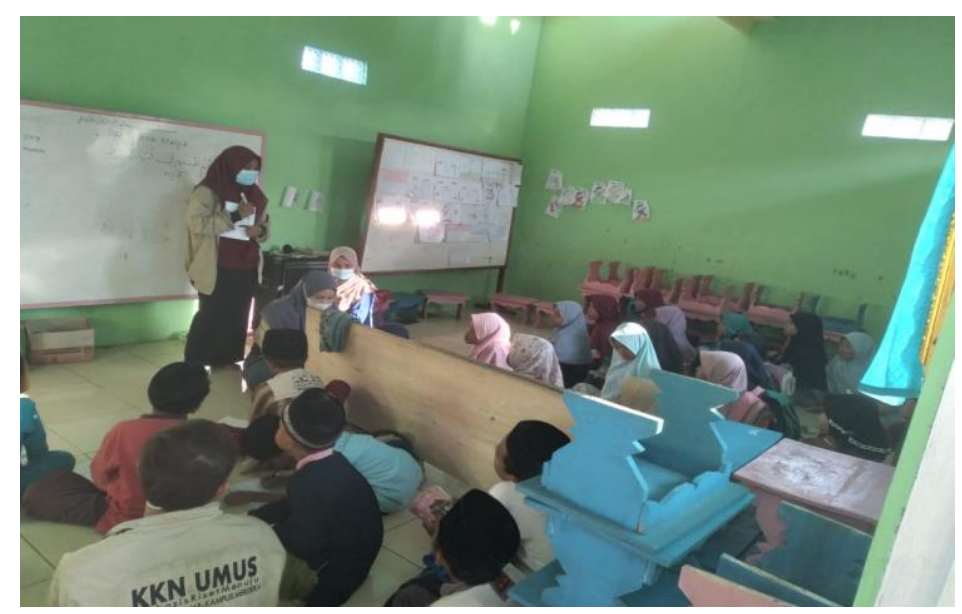


b. Kegiatan Inti Pengabdian

Gambar 1. Pemberian Motivasi, Apersepsi, dan Angket

Pada kegiatan inti pengabdian masyarakat, peserta didik TPA Al-Husna dusun Karang Tengah desa Rungkang diberikan teori mengenai membaca dan menulis puisi menggunakan metode ceramah. Setelah itu, peserta didik diberikan pelatihan menulis puisi dengan tema bebas, yang kemudian dicontohkan bagaimana cara membaca puisi yang sesuai dengan irama dan ritma puisi. Setelah peserta didik diberikan materi dan diberikan pelatihan, peserta didik diberikan penugasan untuk menulis dan membaca puisi yang nantinya akan dijadikan sebagai akhir untuk evaluasi dari pelatihan ini.

Teknik analisis yang digunakan pada kegiatan inti yaitu teknik angket. Teknik angket digunakan untuk mengetahui pemahaman akhir peserta didik TPA Al-Husna dusun Karang Tengah desa Rungkang tentang membaca dan menulis puisi. Sama dengan pemahaman awal bahwa yang ditanyakan dalam angket tersebut yaitu pengertian puisi, bagaimana cara membaca puisi, ciri-ciri menulis puisi, macam-macam puisi, dan langkah-langkah menulis puisi. Pada kegiatan inti pengabdian ini dapat dilihat pada Gambar 2.

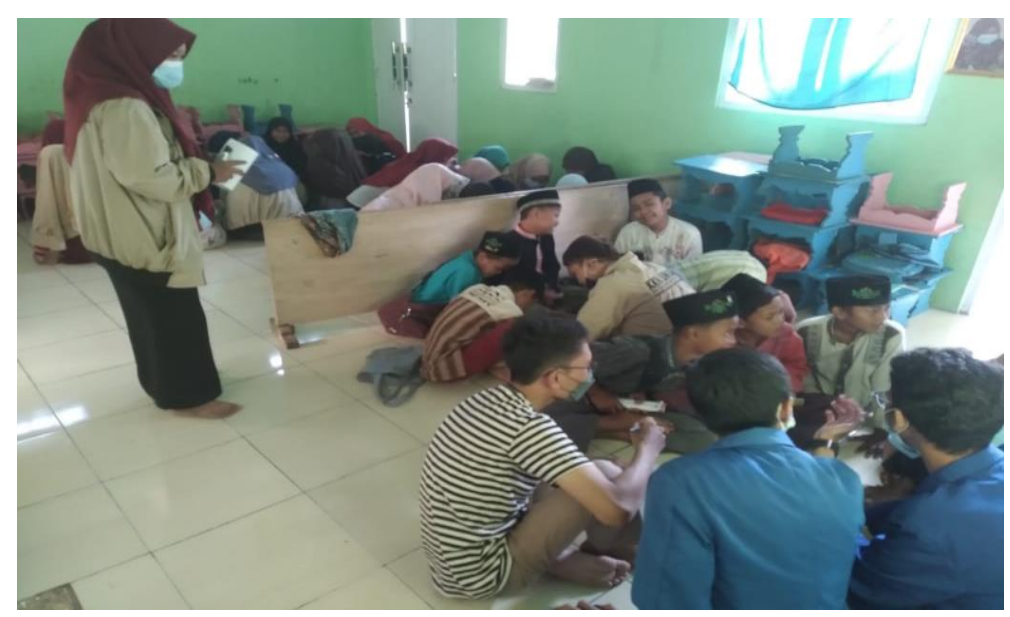

Gambar 2. Pemberian Pelatihan dan Penugasan

\section{HASIL DAN PEMBAHASAN}

Hasil kegiatan pengabdian kepada masyarakat ini berupa pelatihan membaca dan menulis puisi. Kegiatan ini dilakukan di TPA Al-Husna dusun Karang Tengah desa Rungkang. Tahap pertama yaitu pemahaman awal peserta didik TPA Al-Husna tentang membaca dan menulis puisi, kemudian tahap akhir pemahaman akhir dan kemampuan peserta didik dalam membaca dan menulis puisi.

\section{Pemahaman Awal Peserta Didik TPA Al-Husna}

Pemahaman awal ini dilakukan dengan menggunakan angket yang diberikan kepada peserta didik TPA Al-Husna dusun Karang Tengah desa Rungkang. Kemudian peserta didik memberikan tanggapan dan responnya mengenai pertanyaan yang diberikan. Angket tersebut berisi tentang pemahaman membaca dan menulis puisi. Pemahaman tersebut terdiri atas pengertian puisi, bagaimana cara membaca puisi, ciri-ciri menulis puisi, macam-macam puisi, dan langkah-langkah menulis puisi. Hal tersebut tmapak pada Tabel 1.

Tabel 1. Pemahaman Awal Peserta Didik dalam Membaca dan Menulis Puisi

\begin{tabular}{llcl} 
No Aspek & $\begin{array}{c}\text { Jumlah Peserta } \\
\text { Didik yang } \\
\text { Memahami }\end{array}$ & $\begin{array}{c}\text { Jumlah Total } \\
\text { Peserta Didik }\end{array}$ & Prosentasi \\
\hline
\end{tabular}

Pelatihan Membaca dan Menulis Puisi pada Peserta Didik TPA Al-Husna (Tutut Rahayu, Prasetyo Yuli Kurniawan) 


\begin{tabular}{|c|c|c|c|c|}
\hline No & Aspek & $\begin{array}{c}\text { Jumlah Peserta } \\
\text { Didik yang } \\
\text { Memahami }\end{array}$ & $\begin{array}{l}\text { Jumlah Total } \\
\text { Peserta Didik }\end{array}$ & Prosentasi \\
\hline 1 & Pengertian Puisi & 15 & 30 & $40 \%$ \\
\hline 2 & $\begin{array}{l}\text { Bagaimana Cara Membaca } \\
\text { Puisi }\end{array}$ & 10 & 30 & $30 \%$ \\
\hline 3 & Ciri-Ciri Menulis Puisi & 9 & 30 & $27 \%$ \\
\hline 4 & Macam-Macam Puisi & 8 & 30 & $25 \%$ \\
\hline 5 & $\begin{array}{l}\text { Langkah-Langkah Menulis } \\
\text { Puisi. }\end{array}$ & 10 & 30 & $30 \%$ \\
\hline
\end{tabular}

Pada pemaparan Tabel 1. dapat disimpulkan bahwa pemahaman awal peserta didik TPA Al-Husna mengenai membaca dan menulis puisi memiliki rata-rata persentase $\mathbf{3 0 , 4 \%}$. Nilai rata-rata tersebut terdiri atas pengertian puisi yaitu $40 \%$, bagaimana cara membaca puisi $30 \%$, ciri-ciri menulis puisi $27 \%$, macam-macam puisi $25 \%$, dan langkah-langkah menulis puisi $30 \%$.

\section{Pemahaman Akhir dan Keterampilan Peserta Didik TPA Al-Husna}

Pada pemahama akhir menggunakan metode yang sama dengan metode yang digunkan pada pemahaman awal yaitu menggunakan metode angket yang diberikan kepada peserta didik TPA Al-Husna. Namun yang membedakan antara pemahaman awal dan akhir yaitu angket tersebut diberikan setelah peserta diberikan contoh membaca dan menulis puisi. Kemudian peserta didik memberikan tanggapan dan responya terhadap pertanyaan yang diberikan tersebut. Angket tersebut berisi tentang pemahaman membaca dan menulis puisi. Pemahaman tersebut terdiri atas pengertian puisi, bagaimana cara membaca puisi, ciri-ciri menulis puisi, macammacam puisi, dan langkah-langkah menulis puisi.Pemahaman akhir peserta didik dapat disajikan dalam Tabel 2.

Tabel 2. Pemahaman Akhir Peserta didik TPA Al-Husna tentang Membaca dan Menulis Puisi

\begin{tabular}{clccc}
\hline No & Aspek & $\begin{array}{c}\text { Jumlah Peserta } \\
\text { Didik yang } \\
\text { Memahami }\end{array}$ & $\begin{array}{c}\text { Jumlah Total } \\
\text { Peserta Didik }\end{array}$ & Prosentasi \\
\hline $\mathbf{1}$ & Pengertian Puisi & 26 & 30 & $80 \%$ \\
\hline $\mathbf{2}$ & $\begin{array}{l}\text { Bagaimana Cara Membaca } \\
\text { Puisi }\end{array}$ & 23 & 30 & $70 \%$ \\
\hline $\mathbf{3}$ & Ciri-Ciri Menulis Puisi & 22 & 30 & $60 \%$ \\
\hline $\mathbf{4}$ & Macam-Macam Puisi & 20 & 30 & $55 \%$ \\
\hline $\mathbf{5}$ & $\begin{array}{l}\text { Langkah-Langkah Menulis } \\
\text { Puisi. }\end{array}$ & 25 & 30 & $75 \%$ \\
\hline & Nilai rata-rata pemahaman peserta didik & $68 \%$ \\
\hline
\end{tabular}

Pada pemaparan Tabel 2. dapat disimpulkan bahwa pemahaman akhir peserta didik TPA Al-Husna dusun Karang Tengah desa Rungkang tentang membaca dan menulis puisi memiliki rata-rata persentase $68 \%$. Nilai rata-rata tersebut terdiri atas pengertian puisi yaitu $80 \%$, bagaimana cara membaca puisi $70 \%$, ciri-ciri menulis puisi $60 \%$, macam-macam puisi $55 \%$, dan langkah-langkah menulis puisi $75 \%$.

Setelah peserta didik memahami materi tentang membaca dan menulis puisi, peserta didik diberikan pelatihan dan penugasan tentang menulis puisi. Kemudian peserta didik menulis puisi yang bertema bebas. Hasil dari menulis puisi dapat dilihat pada gambar berikut. 

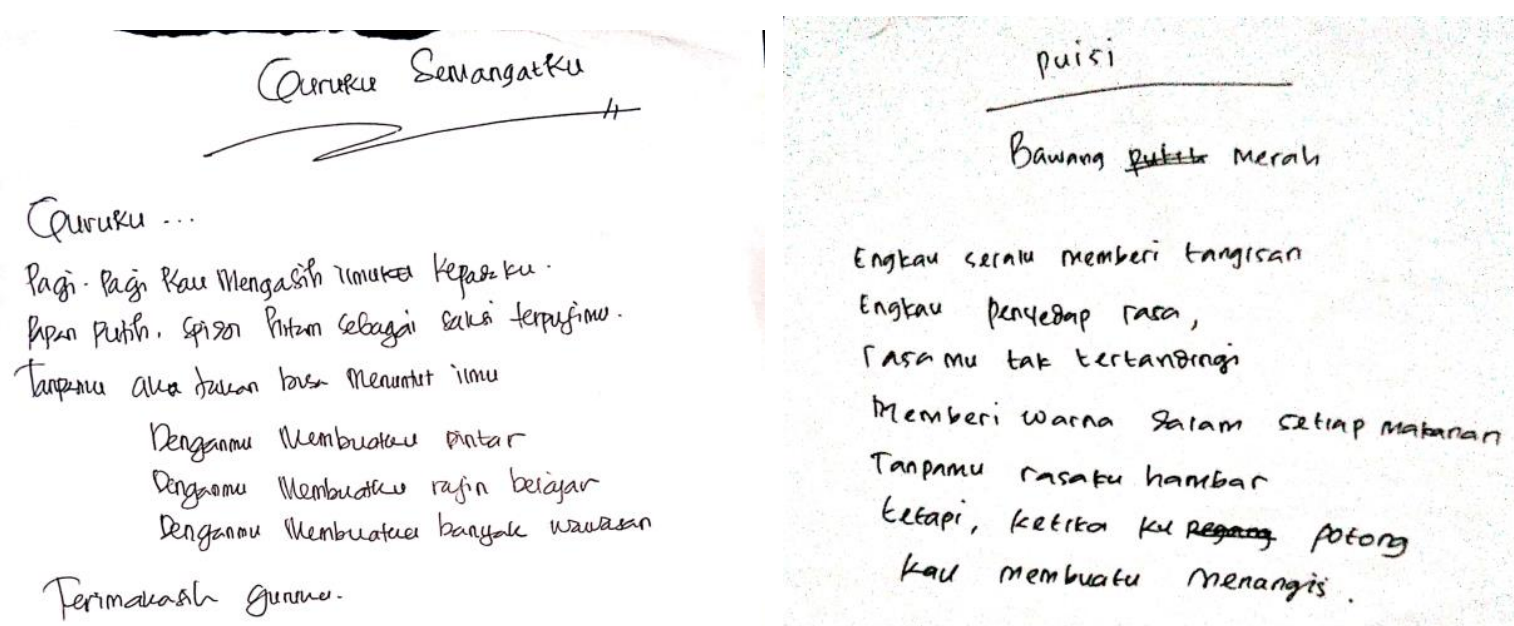

Gambar 3. Hasil Keterampilan Menulis Puisi Peserta Didik TPA Al-Husna

Berdasarkan Gambar 3, dapat disimpulkan bahwa peserta didik TPA Al-Husna sudah mengerti dan mampu untuk merangakai kata-kata menjadi sebuah puisi yang indah sesuai dengan struktur puisi.

\section{KESIMPULAN}

Berdasarkan hasil dan pembahasan pada kegiatan pengabdian masyarakat yaitu "Pelatihan Membaca dan Menulis Puisi pada Peserta Didik TPA Al-Husna", dapat disimpulkan bahwa setelah diberikannya contoh bagimana membaca dan menulis puisi yang terkait dengan puisi, peserta didik menjadi meningkat pemahamannya dan sudah mampu untuk membuat sebuah puisi dan membacakannya sesuai bagaimana cara membaca puisi yang baik yaitu dengan menggunakan irama dan ritma puisi. Hal tersebut menunjukan bahwa pemahaman peserta didik awal dapat di persentase yaitu 30,4\%. Kemudian pemahaman akhir peserta didik yaitu sejumlah $68 \%$. Maka dapat disimpulkan bahwa ada kenaikan 37,60\% dalam pemahaman membaca dan menulis puisi. Selain itu, peserta didik juga terampil dalam merangkai kata-kata menjadi suatu karya yaitu puisi serta sudah mampu untuk membaca puisi yang baik dan benar supaya maksud dari puisi tersebut dapat sampai kepada pendengar.

\section{UCAPAN TERIMAKASIH}

Ucapan terima kasih yang sebesar-besarnya diberikan kepada Kepala TPA Al-Husna, pendidik di TPA Al-Husna, rekan-rekan mahasiswa Universitas Muhadi Setiabudi, dan masyarakt yang secara tidak langsung membantu dan menyukseskan terlaksananya kegiatan pengabdian masyarakat ini. Kemudian kepada Rektor Universitas Muhadi Setiabudi melalui kepala LPPM yang memberikan izin untuk melaksanakan pengabdian masyarakat di dusun Karang Tengah desa Rungkang . 


\section{DAFTAR PUSTAKA}

Afriansya, F., \& Yanti, P. G. (2020). Keterampilan Membaca Puisi Siswa Sebuah Modifikasi Teknik Membaca Puisi Jose Rizal Manua: Jurnal BAHASTRA, 40(1), 29-38. http://dx.doi.org/10.26555/bahastra.v40i1.15286

Kertayasa, W., Suandi, N., \& Utama, D. G. B. (2018). Pembelajaran Menulis Puisi Berdasarkan Pendekatan Kontekstual Pada Siswa Kelas X Mia 2 Sma N 1 Sukasada: Jurnal Pendidikan Dan Bahasa Indonesia Undiksha, 8(2), 248-259. 10.23887/jijpbs.v8i2.20618

Kurniawan, P. Y. ., Nurpratiwiningsih, L. ., Rahayu, T. ., Ulwiyah, N. F. ., Daryati, E. ., Arvin Hakim, M. W. ., \& Yuliandini, V. F. (2021). Pelatihan Menulis Deskripsi dengan menggunakan Media Gambar untuk Menumbuhkan Nilai-Nilai Karakter. JAMU : Jurnal Abdi Masyarakat UMUS, 1 (02). Retrieved from http://jurnal.umus.ac.id/index.php/jamu/article/view/347

Maulidah, T. (2020). Peningkatan Keterampilan Menulis Puisi Dengan Media Gambar: Jurnal Kependidikan, Pembelajaran, dan Pengembangan KARANGAN, 2(1), 64-70. https://ejournal.billfath.ac.id/index.php/karangan/article/view/46/34

Nalenan, J. S. (2020). Pelatihan Menulis Puisi Dengan Media Gambar Pada Siswa Kelas VII SMP Negeri Kota Baru Kefamenan: Jurnal Pengabdian Masyarakat Bakti Cendana, (3) 2, 92-98. https://doi.org/10.32938/bc.v3i2.565

Pradopo, R. D. (2012). Pengkajian Puisi. Gadjah Mada University Press.

Prayogi, E. A. (2017). Peningkatan Kemampuan Menulis Puisi Dengan Menggunakan Teknik Peta Pasang Kata: Jurnal Diksatrasia, 1(2), 57-64. https://jurnal.unigal.ac.id/index.php/diksatrasia/article/view/582/480

Tarigan, H. G. (2013). Menulis Sebagai Suatu keterampilan Berbahasa. Kasa Bandung.

Tarigan, H. G. (2015). Membaca Sebagai Suatu Keterampilan Berbahasa. Angkasa Badung.

Utami, A. M. S., Purwadi, A. J., \& Arifin, M. (2018). Peningkatan Kemampuan Membaca Puisi Melalui Pemodelan Pada Siswa Kelas VII A SMP Negeri 16 Kota Bengkulu: Jurnal Ilmiah Korpus, 2(2), 141-146. https://doi.org/10.33369/jik.v2i2.6516

Yono, R. R. (2020). Pelatihan Membaca Puisi Bagi Siswa Madrasah Diniyah Ta'limul Huda Desa Randusanga Wetan: Cendekia Jurnal Pengabdian Masyarakat, 2(2), 103-109. https://doi.org/10.32503/cendekia.v2i2.858 